Macroeconomic determinants of households' indebtedness in Portugal: what really matters in the era of financialisation?

Ana Romão Ricardo Barradas Dezembro de 2020

WP n.o 2020/06

DOCUMENTO DE TRABALHO

WORKING PAPER

dinamia'cet_iscte

Centro de Estudos sobre a Mudança Socioeconómica e o Território 


\title{
Macroeconomic determinants of households' indebtedness in Portugal: what really matters in the era of financialisation?
}

\author{
Ana Romão* \\ Ricardo Barradas**
}

WP n. $02020 / 06$

DOI: $10.15847 /$ dinamiacet-iul.wp.2020.06

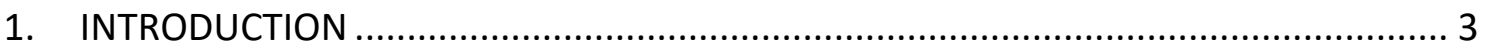

2. LITERATURE REVIEW OF HOUSEHOLDS' INDEBTEDNESS IN THE ERA OF

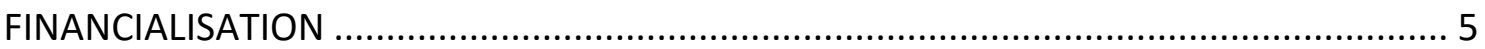

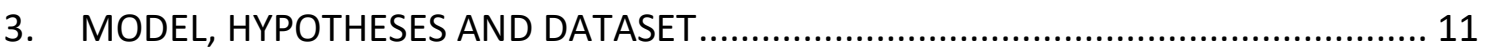

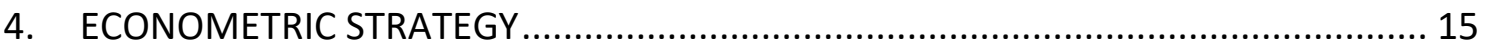

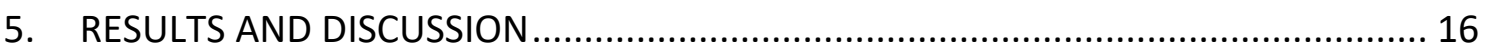

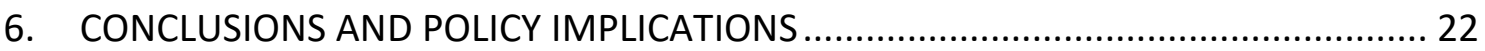

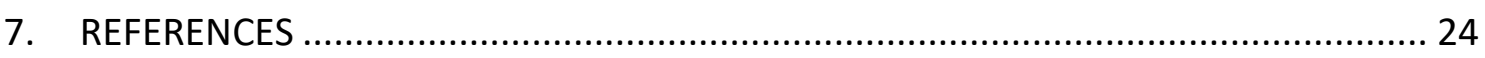

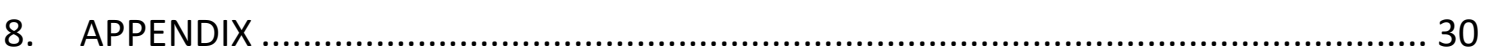

* BNP Paribas Portugal, Lisboa, Portugal, email: analuisaromao@hotmail.com

** Iscte - Instituto Universitário de Lisboa, Dinâmia'CET - Iscte, Lisboa, Portugal. ISCAL - Instituto Superior de Contabilidade e Administração de Lisboa, Instituto Politécnico de Lisboa, Lisboa, Portugal, email: ricardo barradas@iscte-iul.pt (corresponding autor) 


\title{
Macroeconomic determinants of households' indebtedness in Portugal: what really matters in the era of financialisation ${ }^{1}$
}

\begin{abstract}
The objective of this paper is to perform a time series econometric analysis in order to empirically assess the macroeconomic determinants and the corresponding drivers of the Portuguese households' indebtedness in the period 1988 to 2016. During that period, the Portuguese economy experienced a process of financialisation that contributed to an increase in Portuguese households' indebtedness to unprecedented levels. The Portuguese households' indebtedness played a crucial role in the recent sovereign debt crisis. Based on the existing literature, we hypothesize that Portuguese households' indebtedness was due to seven macroeconomic determinants, notably housing prices, financial asset prices, the degree of personal income inequality, households' labour income, the importance of welfare state expenditures, the fraction of the working-age population and the level of interest rates. Our findings reveal that financial asset prices, the degree of personal income inequality, households' labour income and the fraction of the working-age population positively impact Portuguese households' indebtedness, whereas the housing prices negatively impact Portuguese households' indebtedness. Our findings also show that the increase in financial asset prices and the decline in housing prices were the main drivers of Portuguese households' indebtedness in the last few decades.
\end{abstract}

\section{Keywords}

Portugal, Financialisation, Households' Indebtedness, Time Series, Autoregressive Distributed Lag Estimator.

JEL classification - C32, D10, E21 and R20

\footnotetext{
1 The authors thank the helpful comments and suggestions of Diptes Bhimjee, Rúben Barros and Sérgio Lagoa. The usual disclaimer applies.

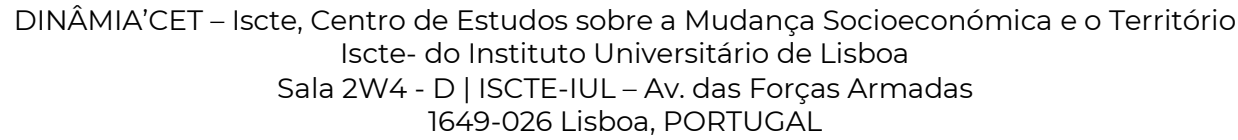




\section{INTRODUCTION}

In 1986, Portugal initiated its process of integration with the European Economic Community, which required the dismantling of the constraints of its financial system. Consequently, the Portuguese financial system has undergone a strong transformation since that time through the privatisation of public financial institutions and the adoption of several liberalising measures. This new deregulatory framework, formed in order to fulfil the European rules, contributed to accelerating the process of financialisation of the Portuguese economy by promoting strong growth of the Portuguese financial system and an increase in Portuguese households' indebtedness to unprecedented levels. The Portuguese households' indebtedness played a central role in the emergence of the recent sovereign debt crisis (Barradas et al., 2018).

Accordingly, one of the main challenges of the Portuguese economy involves the need to adopt public policies that could favour a decline in Portuguese households' indebtedness in order to promote higher financial and macroeconomic stability and resilience and to prevent the emergence of new financial and economic crises in the coming years. This requires a better understanding of the macroeconomic determinants and the respective drivers of Portuguese households' indebtedness.

From a theoretical point of view, Moore and Stockhammer (2018) provide a systematization of the existing literature by identifying eight macroeconomic determinants of households' indebtedness, namely the rise in housing prices, the upward movements in financial asset prices, the increase in personal income inequality, the decline in households' labour income, welfare state retrenchment, the increase in the working-age population, the low level of interest rates and the greater availability of credit.

From an empirical point of view, these macroeconomic determinants of households' indebtedness have been assessed by several econometric studies focused on a single country (Kohn and Dynan, 2007; Oikarinen, 2009; Gimeno and Martinez-Carrascal, 
2010; Valverde and Fernandez, 2010; Meng et al., 2013; Anundsen and Jansen, 2013) and centred on a group of countries (Malinen, 2016; Rubaszek and Serwa, 2014; Klein, 2015; Stockhammer and Wildauer, 2018; Moore and Stockhammer, 2018). Nevertheless, these econometric studies do not incorporate all the aforementioned eight macroeconomic determinants of households' indebtedness. Moore and Stockhammer's (2018) study is the only exception as it analyses all of them except for the greater availability of credit, which was omitted due to the inexistence of an available proxy. They perform a panel data econometric analysis for thirteen countries of the Organisation for Economic Cooperation and Development (Australia, Belgium, Canada, Finland, France, Germany, Italy, Japan, Norway, Spain, Sweden, the United Kingdom and the United States) for the period 1993 to 2011. They conclude that the most robust macroeconomic determinant of households' indebtedness is housing prices.

This paper analyses the macroeconomic determinants and the corresponding drivers of Portuguese households' indebtedness in the period 1988 to 2016 and makes a fourfold contribution to the existing literature. Firstly, this paper is focused on Portugal. Portugal is a very interesting case study. Portuguese households are some of the most indebted among the other European countries. In Portugal, housing credit represents more than $80 \%$ of that indebtedness (Barradas et al., 2018). Secondly, this paper performs a time series econometric analysis by incorporating seven of the aforementioned eight macroeconomic determinants of households' indebtedness, which had only been done by Moore and Stockholmer (2018). This allows us to mitigate the problem linked to omitted relevant variables and obtain estimates that are more consistent and unbiased (Wooldridge, 2003; Kutner et al., 2005; Brooks, 2009). Thirdly, this paper incorporates a higher sample variability by including periods of increase and periods of decrease in Portuguese households' indebtedness (Figure A1 in the Appendix). Fourthly, this paper identifies not only the macroeconomic determinants of Portuguese households' indebtedness but also the respective drivers. This allows us identify the contribution of each macroeconomic determinant to the evolution of Portuguese households' indebtedness in the last few decades. 
By relying on the Autoregressive Distributed Lag (ARDL) estimator, due to the existence of variables that are stationary in levels and variables that are stationary in first differences, we conclude that financial asset prices, the degree of personal income inequality, households' labour income and the fraction of the working-age population exert positive impacts on Portuguese households' indebtedness, whereas the housing prices exert a negative impact on Portuguese households' indebtedness. We also conclude that the increase in financial asset prices and the decline in housing prices were the main drivers of Portuguese households' indebtedness in the last few decades.

The remainder of the paper is organized as follows. Section 2 contains a brief literature review of households' indebtedness in the era of financialisation. In Section 3, we present our model, hypotheses and the respective dataset. Econometric strategy is described in Section 4. In Section 5, we present the results and the corresponding discussion. Finally, Section 6 concludes by emphasising some policy implications and suggestions for future research.

\section{LITERATURE REVIEW OF HOUSEHOLDS' INDEBTEDNESS IN THE ERA OF FINANCIALISATION}

One distinctive feature in the era of financialisation is the higher and stronger engagement of households, including low-income and middle-class households, in the sphere of finance. This engagement has occurred through the acquisition of financial assets as well as the contracting of financial the liabilities (Stockhammer, 2010; Lapavitsas, 2011; Van der Zwan, 2014; Barradas, 2016). On the one hand, households are now holding more financial assets, such as life insurance pensions, other insurance products, money market funds, deposits, bonds, stocks and other financial assets. On the other hand, households are now also contracting more financial liabilities, such as credits, credit cards and overdraft bank charges.

As a consequence, households' indebtedness has seen a steep increase in the era of financialisation to unprecedented levels, particularly until the Great Recession (Barradas

\footnotetext{
DINÂMIA'CET - Iscte, Centro de Estudos sobre a Mudança Socioeconómica e o Território Iscte- do Instituto Universitário de Lisboa Sala 2W4 - D | ISCTE-IUL - Av. das Forças Armadas 1649-026 Lisboa, PORTUGAL

Tel. (+351) 210464031 / 210464197 | E-mail: dinamia@iscte-iul.pt | www.dinamiacet.iscte-iul.pt
} 
et al., 2018; Barradas, 2020). Households' indebtedness even played a central role in the emergence of the last financial and economic crisis (Mian and Sufi, 2014; Moore and Stockhammer, 2018).

This infers the need to identify the correct macroeconomic determinants and the respective drivers of households' indebtedness in order to design better public policies that could contribute to decreasing households' indebtedness, to ensuring higher financial and macroeconomic stability and resilience, and to preventing the emergence of new financial and economic crises in the coming years.

Moore and Stockhammer (2018) extracted from the existing literature eight macroeconomic determinants of households' indebtedness, which are based on three different groups of explanations and supported by different strands of literature. Figure 1 illustrates these eight macroeconomic determinants and both the categories of explanations and the strands of literature that each one belongs to.

\section{Figure 1 - Macroeconomic Determinants of Households' Indebtedness}

\begin{tabular}{|c|c|c|}
\hline \multirow{3}{*}{$\begin{array}{l}\text { Households' } \\
\text { Indebtedness }\end{array}$} & $\begin{array}{c}\text { Asset-Transaction Explanations } \\
\text { (Post Keynesians and Consumption Wealth Effects) }\end{array}$ & $\begin{array}{l}\text { Rising Housing Prices } \\
\text { Upward Movements in Financial Asset } \\
\text { Prices }\end{array}$ \\
\hline & $\begin{array}{c}\text { Consumption-Oriented Explanations } \\
\text { (Behavioural Economics, Post Keynesians and Life } \\
\text { Cycle Models) }\end{array}$ & $\begin{array}{l}\text { Rising Personal Income Inequality } \\
\text { Decline in Households' Labour Income } \\
\text { Welfare State Retrenchment } \\
\text { Increase in Working-Age Population }\end{array}$ \\
\hline & Monetary Policy and Credit Supply Explanations & $\begin{array}{l}\text { Low Interest Rates } \\
\text { Greater Availability of Credit }\end{array}$ \\
\hline
\end{tabular}

Source: Authors' representation based on Moore and Stockhammer (2018)

The first macroeconomic determinant of households' indebtedness is linked to the rise in housing prices, which can be explained by two different mechanisms (Godley and Lavoie, 2007; Ryoo, 2016). Firstly, a surge in housing prices has a direct effect in the rise of households' wealth, which stimulates consumption that can be realised through mortgage 
equity withdrawals. This is the 'realised wealth effect' (Ludwig and Sløk, 2001). Secondly, a surge in housing prices implies an increase in the value of collateral, which relaxes households' credit constraints and allows them to acquire more debt. This is the 'liquidity constraints effect' (Ludwig and Sløk, 2001) and it rests on the financial accelerator theory, according to which asset price inflation increases the value of collateral by permitting more borrowing (Bernanke et al., 1996).

The second macroeconomic determinant of households' indebtedness is related to the rise in prices of financial assets owned by households, which drive them to incur more debt as leverage to acquire more financial assets (Cooper and Dynan, 2016). Households are also holding more financial assets because of the emergence of remuneration schemes to employees in the form of stock options, in addition to purely cash, in the era of financialisation (Edison and Sløk, 2011). As emphasised by Hein (2012), housing and stock market price boom episodes have increased (notional or virtual) households' wealth, against which they were willing to borrow in the era of financialisation.

The third macroeconomic determinant of households' indebtedness is associated with the rise in personal income inequality (Frank et al. 2014), which is mainly visible through the rise in income of the richest in the last years. This a well-recognized stylized fact in the era of financialisation (Tridico and Pariboni, 2018), which has occurred due to the abandonment of full employment goals; the proliferation of the 'shareholder value orientation'; the excessive managerial focus on short-term profitability to satisfy impatient shareholders; the appearance of multinational corporations that systematically threaten to relocate their production to low-wage countries; the deregulation of labour markets in order to promote higher wage flexibility (e.g., lesser protection against firing and/or a lower level of unemployment benefits); the emergence of practices such as outsourcing; and the decline of the power of trade unions. This has increased the vulnerability of unskilled labour and/or low-skilled labour and has given rise to asymmetries in income distribution, leading the poorest households to incur debt to copy the consumption standards of the richest households. This is the 'demonstration effect' or 'Duesenberry effect' (Duesenberry, 1949). This 'expenditure cascades' behaviour (Frank 
et al., 2014) or 'keeping up with the Joneses' behaviour suggests that households aspire to the lifestyle and consumption levels of their neighbours or other households, mainly through the acquisition of Veblen and other durable goods that allow them to satisfy conspicuous consumption through debt.

The fourth macroeconomic determinant of households' indebtedness is the decline in households' labour income, which is essentially explained by technological progress, globalisation, neoliberalism and financialisation since the mid-1980s (Barradas and Lagoa, 2017; Tridico and Pariboni, 2018; Barradas, 2019). The fall in households' labour income led them to incur more debt in order to prevent a loss in their standard of living. They had become accustomed to a certain standard of living and did not want other households to think they had lost it (Barba and Pivetti, 2008; Stockhammer, 2012, 2015). This is the 'ratchet effect' (Duesenberry, 1949). This is particularly relevant due to the general recognition of the consumption inertia or sluggishness due to the existence of households' consumption habits (Barradas, 2020).

The fifth macroeconomic determinant of households' indebtedness pertains to welfare state retrenchment in the era of neoliberalism and financialisation all over the world, which has implied a fall in the quantity and/or the quality of public provision in some social areas such as housing, health, education, pensions and transportation, among others. Against this backdrop, households incur debt in order to satisfy their basic needs that previously were fully satisfied by the State and/or to cover some risks that previously were fully covered by the State (Finlayson, 2009; Lapavitsas, 2013).

The sixth macroeconomic determinant of households' indebtedness is the increase in the working-age population, which is the fraction of the population that naturally incurs and accumulates debt (Modigliani and Brumberg, 1954). Non-working young people do not have any debt because they are fully credit-constrained, and the non-working elderly population tend to spend their savings. 
The seventh macroeconomic determinant of households' indebtedness corresponds to the low level of interest rates, which naturally stimulates households to incur more debt due to the correspondingly cheaper costs of borrowing (Taylor, 2009).

The eighth and last macroeconomic determinant of households' indebtedness is related to the greater availability of credit in the era of financialisation, which has occurred due to financial innovation and engineering (e.g., debt securitisation and the 'originate to distribute' operations of banks) (Hein, 2012), greater competition among banks (Boone and Girouard, 2002) and the corresponding adoption of more aggressive commercial policies in the credit segment (Stockhammer, 2009), the emergence of new financial instruments (e.g., home equity loans and credit cards) (Hein, 2012) and the loosening of financial regulations (Justiano et al., 2019). These features have resulted in a deterioration in creditworthiness standards and have made credit increases possible for the majority of households (Hein, 2012).

Empirically, there are already in the literature several works that perform time series econometric analyses focused on a single country (Kohn and Dynan, 2007; Oikarinen, 2009; Gimeno and Martinez-Carrascal, 2010; Valverde and Fernandez, 2010; Meng et al., 2013; Anundsen and Jansen, 2013) and panel data econometric analyses centred on a group of countries (Malinen, 2016; Rubaszek and Serwa, 2014; Klein, 2015; Stockhammer and Wildauer, 2018; Moore and Stockhammer, 2018) to assess the macroeconomic determinants of households' indebtedness.

Nonetheless, these empirical works do not incorporate all the aforementioned eight macroeconomics determinants of households' indebtedness, but only some of them isolated from each other, which suggests that they do not assess correctly and completely what the macroeconomic causes are for the unprecedented levels of households' indebtedness reached in the last few years. In addition, by excluding some explanations, their results suffer from the problem linked to omitted relevant variables, which indicates that their estimates may be inconsistent and/or biased (Wooldridge, 2003; Kutner et al., 2005; Brooks, 2009).

\footnotetext{
DINÂMIA'CET - Iscte, Centro de Estudos sobre a Mudança Socioeconómica e o Território Iscte- do Instituto Universitário de Lisboa Sala 2W4 - D | ISCTE-IUL - Av. das Forças Armadas 1649-026 Lisboa, PORTUGAL 
Moore and Stockhammer's (2018) study is the most complete empirical work because it includes seven of the aforementioned eight macroeconomic determinants of households' indebtedness. The macroeconomic determinant related to the availability of credit was the only one that needed to be excluded due to the inexistence of an available proxy to properly assess it. All of the remaining seven macroeconomic determinants were considered. They performed a panel data econometric analysis for thirteen countries of the Organisation for Economic Co-operation and Development (Australia, Belgium, Canada, Finland, France, Germany, Italy, Japan, Norway, Spain, Sweden, the United Kingdom and the United States) for the period between 1993 and 2011 by relying on the panel error correction models to produce their estimates. They found that housing prices are one of the most prominent macroeconomic determinants of households' indebtedness both in the long-term or in the short-term. The remaining macroeconomic determinants were proven to not exert robust influences on households' indebtedness. A positive relationship between housing prices and households' indebtedness was also found by other empirical studies on this subject (Kohn and Dynan, 2007; Oikarinen, 2009; Gimeno and Martinez-Carrascal, 2010; Valverde and Fernandez, 2010; Meng et al., 2013; Anundsen and Jansen, 2013; Rubaszek and Serwa, 2014; Stockhammer and Wildauer, 2018).

Our paper, resembling the empirical work of Moore and Stockhammer (2018), aims to assess the macroeconomic determinants and the concomitant drivers of Portuguese households' indebtedness by introducing four important novelties to the existing literature. Firstly, our empirical study is focused on Portugal. Secondly, our time series econometric analysis incorporates the majority of the aforementioned macroeconomic determinants of households' indebtedness. Thirdly, our sample includes periods of increase and periods of decrease in households' indebtedness. Fourthly, our empirical work also identifies the drivers of Portuguese households' indebtedness. 


\section{MODEL, HYPOTHESES AND DATASET}

Against this backdrop, we propose to estimate an equation according to which households' indebtedness is a function of the seven macroeconomic determinants identified previously, i.e., housing prices, financial asset prices, the degree of personal income inequality, households' labour income, the importance of welfare state expenditures, the fraction of the working-age population and the level of interest rates. Like Moore and Stockhammer (2018), we do not include in our equation the macroeconomic determinant related to the availability of credit due to the lack of a proxy that can properly assess this macroeconomic determinant for Portugal.

Our long-term equation for households' indebtedness takes the following form:

$$
H I_{t}=\beta_{0}+\beta_{1} H P_{t}+\beta_{2} F A P_{t}+\beta_{3} I N_{t}+\beta_{4} L I_{t}+\beta_{5} W S_{t}+\beta_{6} W P_{t}+\beta_{7} I R_{t}+\alpha_{t}
$$

where $\mathrm{t}$ is the time period (years), HI is the households' indebtedness, HP is the housing prices, FAP is the financial asset prices, IN is the degree of personal income inequality, LI is the households' labour income, WS is the importance of the welfare state expenditures, WP is the fraction of the working-age population, IR is the level of interest rates and $\alpha$ is an independent and identically distributed (white noise) disturbance term with null average and constant variance (homoscedastic).

As discussed previously, we expect that the housing prices, financial asset prices, the degree of personal income inequality and the fraction of working-age population will exert a positive influence on households' indebtedness, whereas the households' labour income, the importance of the welfare state expenditures and the level of interest rates are expected to exert a negative influence. Our hypotheses therefore suggest the following signs for the coefficients of our variables:

\footnotetext{
DINÂMIA'CET - Iscte, Centro de Estudos sobre a Mudança Socioeconómica e o Território Iscte- do Instituto Universitário de Lisboa Sala 2W4 - D | ISCTE-IUL - Av. das Forças Armadas 1649-026 Lisboa, PORTUGAL 


$$
\beta_{1}>0, \beta_{2}>0, \beta_{3}>0, \beta_{4}<0, \beta_{5}<0, \beta_{6}>0, \beta_{7}<0,
$$

In order to fulfil this purpose, we collect annual data for Portugal for the period 1988 to 2016. The frequency and the period were chosen according to the data available for all the variables. Households' indebtedness is measured by the total credit to households and non-profit institutions serving households in percentage of the gross domestic product, available in the Fred St. Louis database. Housing prices corresponds to the natural logarithm of the real housing price index $(2015=100)$, available in the analytical housing prices indicators in the OECD database. Financial asset prices are proxied by the natural logarithm of the real total share prices index for Portugal $(2015=100)$ from the Fred St. Louis database. We assessed the degree of personal income inequality through the top $1 \%$ income share, available in the World Inequality database. Households' labour income is quantified by the adjusted labour share, i.e., the ratio of the compensation of employees per employee to the gross domestic product at current market prices per employee, available in the AMECO database. We measured the importance of the welfare state expenditures by the ratio of the government spending on education, health and social security to the gross domestic product. Both variables were collected from the PORDATA database. The fraction of the working-age population corresponds to the activity rate, i.e., the total active population divided by the total population aged between 15 and 64 years, extracted directly from the PORDATA database. The level of interest rates is assessed by using the real short-term interest rates, available in the AMECO database.

Plots of these variables are provided in Figure A1 in the Appendix, the descriptive statistics are in Table 1 and the correlation matrix is presented in Table 2. With regard to correlations, the majority of them are less than 0.8 , which is the traditional rule of thumb for excluding the existence of multicollinearity between the variables (Studenmund, 2005). For the remaining ones, we proceed with the calculation of the variance inflation factors, and the hypothesis of multicollinearity was also rejected because all of them 
proved to be less than 10 , which is the traditional rule of thumb for excluding the existence of multicollinearity between the variables (Kutner et al., 2004). ${ }^{2}$ At the traditional significance levels, all the independent variables are correlated with the households' indebtedness, with the exception of the fraction of the working-age population. As expected, the correlation between the financial asset prices and households' indebtedness is positive, and the correlations between households' labour income and households' indebtedness and between the level of interest rates and households' indebtedness are both negative.

Table 1 - The descriptive statistics

\begin{tabular}{c|c|c|c|c|c|c|c}
\hline Variable & Mean & Median & Maximum & Minimum & $\begin{array}{c}\text { Standard } \\
\text { Deviation }\end{array}$ & Skewness & Kurtosis \\
\hline Households' Indebtedness & 0.582 & 0.679 & 0.914 & 0.152 & 0.284 & -0.357 & 1.533 \\
House Prices & 4.789 & 4.812 & 4.938 & 4.545 & 0.113 & -0.754 & 2.529 \\
Financial Asset Prices & 4.268 & 4.537 & 5.067 & 3.174 & 0.549 & -0.764 \\
Personal Income Inequality & 0.086 & 0.088 & 0.098 & 0.071 & 0.008 & -0.457 & 2.144 \\
Households' Labour Income & 0.573 & 0.581 & 0.606 & 0.510 & 0.028 & -0.709 & 2.455 \\
Welfare State Expenditures & 0.134 & 0.134 & 0.175 & 0.079 & 0.030 & -0.440 \\
Working-Age Population & 0.605 & 0.610 & 0.638 & 0.576 & 0.018 & -0.210 & 1.008 \\
Interest Rates & 0.014 & 0.005 & 0.075 & -0.020 & 0.027 & 0.774 & 2.580 \\
\hline
\end{tabular}

Table 2 - The correlation matrix

\begin{tabular}{|c|c|c|c|c|c|c|c|c|}
\hline & HI & HP & FAP & IN & LI & WS & WP & IR \\
\hline HI & 1.000 & & & & & & & \\
\hline HP & $-0.454 * *$ & 1.000 & & & & & & \\
\hline FAP & $0.871 * * *$ & $-0.349 *$ & 1.000 & & & & & \\
\hline IN & $-0.531 * * *$ & $0.882 * * *$ & $-0.348^{*}$ & 1.000 & & & & \\
\hline LI & $-0.340 *$ & $0.845^{* * *}$ & -0.195 & $0.863 * * *$ & 1.000 & & & \\
\hline WS & $0.953 * * *$ & $-0.556 * * *$ & $0.856 * * *$ & $-0.572 * * *$ & $-0.372 * *$ & 1.000 & & \\
\hline WP & 0.128 & $0.317 *$ & -0.047 & 0.036 & 0.052 & -0.118 & 1.000 & \\
\hline IR & $-0.683 * * * *$ & $0.378 * *$ & $-0.740 * * *$ & $0.447 * *$ & $0.416 * *$ & $-0.652 * * *$ & -0.127 & 1.000 \\
\hline
\end{tabular}

Note: *** indicates statistical significance at $1 \%$ level, ** indicates statistical significance at $5 \%$ level and * indicates statistical significance at $10 \%$ level

2 Results of the variance inflation factors are available upon request.

DINÂMIA'CET - Iscte, Centro de Estudos sobre a Mudança Socioeconómica e o Território Iscte- do Instituto Universitário de Lisboa

Sala 2W4 - D | ISCTE-IUL - Av. das Forças Armadas

1649-026 Lisboa, PORTUGAL

Tel. (+351) 210464031 / 210464197 | E-mail: dinamia@iscte-iul.pt | www.dinamiacet.iscte-iul.pt 
Table 3 - P-values of the ADF unit root test

\begin{tabular}{c|c|c|c|c|c|c}
\hline \multirow{2}{*}{ Variable } & \multicolumn{3}{|c|}{ Level } & \multicolumn{3}{c}{ First Difference } \\
\cline { 2 - 6 } & Intercept & $\begin{array}{c}\text { Trend and } \\
\text { Intercept }\end{array}$ & None & Intercept & $\begin{array}{c}\text { Trend and } \\
\text { Intercept }\end{array}$ & $\begin{array}{c}\text { None } \\
\text { House Prices }\end{array}$ \\
Financial Asset Prices & $0.051^{*}$ & 0.991 & 0.303 & 0.801 & $0.577^{*}$ & 0.313 \\
Personal Income Inequality & 0.400 & $0.328^{*}$ & 0.550 & 0.062 & 0.270 & $0.005^{*}$ \\
Households' Labour Income & 0.926 & 0.951 & 0.907 & 0.006 & $0.010^{*}$ & 0.000 \\
Welfare State Expenditures & 0.954 & $0.162^{*}$ & 0.383 & 0.000 & $0.000^{*}$ & 0.000 \\
Working-Age Population & $0.116^{*}$ & $0.639^{*}$ & 0.434 & 0.006 & $0.001^{*}$ & 0.000 \\
Interest Rates & 0.635 & 0.971 & 0.000 & $0.055^{*}$ & 0.000 \\
\hline
\end{tabular}

Note: The lag lengths were selected automatically based on the AIC criteria and * indicates the exogenous variables included in the test according to the AIC criteria

Table 4 - P-values of the PP unit root test

\begin{tabular}{c|c|c|c|c|c|c}
\hline \multirow{2}{*}{ Variable } & \multicolumn{3}{|c|}{ Level } & \multicolumn{3}{c}{ First Difference } \\
\cline { 2 - 6 } & Intercept & $\begin{array}{c}\text { Trend and } \\
\text { Intercept }\end{array}$ & None & Intercept & $\begin{array}{c}\text { Trend and } \\
\text { Intercept }\end{array}$ & None \\
\hline Households' Indebtedness & 0.528 & $0.999^{*}$ & 0.843 & 0.840 & $0.650^{*}$ & 0.358 \\
House Prices & 0.711 & $0.492^{*}$ & 0.553 & 0.063 & 0.272 \\
Financial Asset Prices & $0.561^{*}$ & 0.803 & 0.887 & 0.007 & 0.033 & $0.005^{*}$ \\
Personal Income Inequality & 0.818 & $0.156^{*}$ & 0.492 & 0.000 & $0.000^{*}$ & 0.000 \\
Households' Labour Income & 0.954 & $0.479^{*}$ & 0.434 & 0.006 & $0.000^{*}$ & 0.000 \\
Welfare State Expenditures & 0.322 & $0.711^{*}$ & 0.976 & 0.000 & $0.000^{*}$ & 0.000 \\
Working-Age Population & $0.391^{*}$ & 0.687 & 0.434 & 0.001 & 0.004 & $0.001^{*}$ \\
Interest Rates & 0.424 & $0.080^{*}$ & 0.120 & 0.000 & 0.001 & $0.000^{*}$ \\
\hline
\end{tabular}

Note: * indicates the exogenous variables included in the test according to the AIC criteria

The conventional augmented Dickey and Fuller (1979) (ADF) unit root test for each variable is in Table 3 and the Phillips and Perron (1998) (PP) unit root test for each variable is in Table 4 . The results of both tests are quite similar for the majority of variables. Effectively, the housing prices, financial asset prices, the degree of personal income inequality, households' labour income, the importance of welfare state expenditures and the fraction of the working-age population are non-stationary in levels and stationary in first differences by both tests, i.e., they are integrated of order one. Households' indebtedness is stationary in levels according to the ADF test, and the level of the interest rates is also stationary in levels according to the PP test, i.e., they are integrated of order zero.

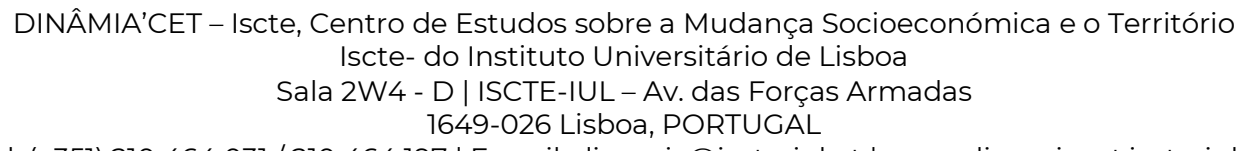

Tel. (+351) 210464031 / 210464 197 | E-mail: dinamia@iscte-iul.pt | www.dinamiacet.iscte-iul.pt 


\section{ECONOMETRIC STRATEGY}

Our econometric strategy involves the implementation of the ARDL estimator developed by Pesaran (1997), Pesaran and Shin (1999) and Pesaran et al. (2001) due to the existence of a dataset composed of a mixture of variables that are integrated of order zero and variables that are integrated of order one. This estimator allows us to work with variables in levels, i.e., without differentiating them, which facilitates the economic interpretation of the obtained coefficients. The EViews software (version 10) is used to obtain our estimates.

This econometric strategy has five steps. The first step corresponds to the determination of the number of lags that should be included in the ARDL to produce our estimates. In fact, and according to the ARDL estimator, the characteristics of households' indebtedness will be modelled using its lagged values and the contemporaneous and lagged values of the independent variables.

The second step is the assessment of the existence of a cointegrating relationship between all the variables by the bounds test procedure developed by Pesaran et al. (2001). As we have a relatively small sample, we will analyse the existence of a cointegrating relationship by relapsing on the critical values for the bounds test developed by Narayan (2005).

The third step is the analysis of several diagnostic tests in order to confirm that our estimates are reliable, namely to confirm that residuals are not serially correlated, are normal and are homoscedastic, that our model is correctly specified in its functional form and that our estimates are stable and do not present any structural breaks.

The fourth step is the presentation of our long-term and short-term estimates, which allows us to identify the determinants of households' indebtedness in Portugal. To produce our estimates, we will take into account the case number four, i.e., an unrestricted constant and a restricted trend, in order to reflect the specific features of each year in the characteristics of households' indebtedness in Portugal. 
The fifth step corresponds to the analysis of the economic effects of our estimates (McCloskey and Ziliak, 1996; Ziliak and McCloskey, 2004). This will allow us to identify the contribution of each statistically significant variable to Portuguese households' indebtedness from 1988 to 2016.

\section{RESULTS AND DISCUSSION}

We start by defining the number of lags that should be included in the ARDL to produce our estimates. We use only one lag because this is the traditional rule of thumb for annual data. Moreover, the use of more lags will imply that the unrestricted VAR would not satisfy the stability condition with more than one characteristic polynomial root outside the unit circle (Lütkepohl, 1991). ${ }^{3}$

Table 5 provides the bounds test procedure in order to assess the existence of a cointegrating relationship between our variables. Note that the estimated F-Statistic is higher than the upper-bound critical values at the traditional significance levels, which means that our variables are strongly cointegrated.

Table 5 - Bounds test

\begin{tabular}{c|c|c|c}
\hline F-Statistic & Critical Value & Lower Bound Value & Upper Bound Value \\
\hline \multirow{3}{*}{36.832} & $1 \%$ & 4.490 & 6.328 \\
& $5 \%$ & 3.194 & 4.604 \\
& $10 \%$ & 2.681 & 3.887 \\
\hline
\end{tabular}

Note: Critical values for the lower bound and upper bound are from Narayan (2005)

Table 6 provides the results of the diagnostic tests. Five conclusions deserve our attention. Firstly, the Breusch-Godfrey test indicates that residuals are not serially correlated. Secondly, the Jarque-Bera test reveals that residuals are normal. Thirdly, the Breusch-

\footnotetext{
${ }^{3}$ Results of the stability condition are available upon request.

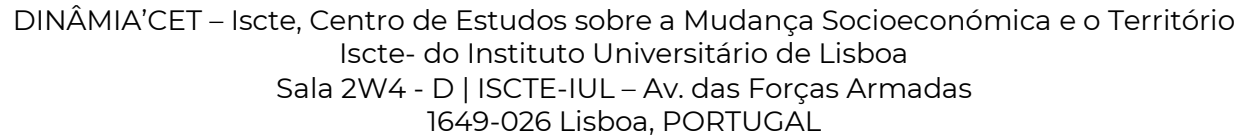


Pagan-Godfrey test confirms that residuals are homoscedastic. Fourthly, Ramsey's RESET test highlights that our model is well specified in its functional form. Fifthly, the CUSUM test (Figure A2 in the Appendix) and the CUSUMSQ test (Figure A3 in the Appendix) strongly support the inexistence of structural breaks and the concomitant stability of our estimates in all periods of our sample. These diagnostic tests tell us that our estimates are quite reliable because our model does not suffer from any econometric problem.

Table 6 - Diagnostic tests

\begin{tabular}{c|c|c}
\hline Diagnostic Test & F-Statistic & P-value \\
\hline Breusch-Godfrey & 0.169 & 0.687 \\
Jarque-Bera & 0.805 & 0.669 \\
Breusch-Pagan-Godfrey & 0.853 & 0.604 \\
Ramsey's RESET & 2.303 & 0.151 \\
\hline
\end{tabular}

Note: Breusch-Godfrey test was conducted with 1 lag and Ramsey's RESET test was performed with 1 fitted term, albeit results do not change if we had used more lags and more fitted terms, respectively

Table 7 exhibits the long-term estimates for Portuguese households' indebtedness. At the conventional significance levels, all variables are statistically significant with the exception of welfare state expenditures and interest rates. ${ }^{4}$ These results seem to suggest that the hypotheses on welfare state retrenchment and the low level of interest rates do not explain Portuguese households' indebtedness. On the one hand, the rise in the welfare state expenditures in Portugal in the few decades due to its late consolidation (Lagoa and Barradas, 2020) seems to suggest a rise in the corresponding social protection, which tends to dissuade households from more precautionary saving and to encourage them to consume more by incurring debt because they feel fully protected by the State. This is the 'free-rider problem', which is more common in more generous welfare states (Homburg, 2000). On the other hand, the insignificance of public housing, the malfunctioning of the rental market for housing purposes and the existence of mortgages subsidized by the

${ }^{4}$ Please note that these results do not change if we use nominal short-term interest rates instead of the real short-term interest rates. Results available upon request. 
Portuguese government until at least the end of 2002 have favoured households buying homes through housing credit despite the cost of the respective borrowing (Barradas et al., 2018). The statistical insignificance of the welfare state expenditures and of the interest rates was also found by Moore and Stockhammer (2018). The remaining variables are statistically significant, albeit the housing prices and households' labour income exhibit counterintuitive impacts on Portuguese households' indebtedness. Housing prices exert a negative influence on Portuguese households' indebtedness, which is not in line with the majority of empirical works on this subject (Kohn and Dynan, 2007; Oikarinen, 2009; Gimeno and Martinez-Carrascal, 2010; Valverde and Fernandez, 2010; Meng et al., 2013; Anundsen and Jansen, 2013; Rubaszek and Serwa, 2014; Stockhammer and Wildauer, 2018; Moore and Stockhammer). ${ }^{5}$ The negative impact of housing prices on Portuguese households' indebtedness could be attributed to the decision to postpone home buying when there is a surge in the respective prices. This household behaviour is very relevant in Portugal, considering that wages are low, the savings rate is too small and the majority of a household's debt is due to buying a permanent home. Thus, a surge in housing prices worsens households' credit constraints and makes it difficult for them to take on more debt. Note also that after the Great Recession, the Portuguese commercial banks were prohibited by the Bank of Portugal from granting housing credits in the total amount corresponding to the home price. Now they just grant housing credit up to $90 \%$ of the minimum value between the value of the appraisal and that of the acquisition. The positive impact of households' labour income on Portuguese households' indebtedness was also reported by Valverde and Fernandez (2010) for the Spanish economy. This result could be associated with the higher conservative stance of the Portuguese banks, according to which the level of households' wages is still the best means of assessing risk of them when they want credit. Financial asset prices exert a positive effect on Portuguese households' indebtedness, which is in accordance with the theoretical claims that upward movements in financial asset prices lead households to incur debt in order to buy more

\footnotetext{
${ }^{5}$ Please note that these results do not change if we use the natural logarithm of the nominal housing price index instead the natural logarithm of the real housing price index $(2005=100)$. Results available upon request.

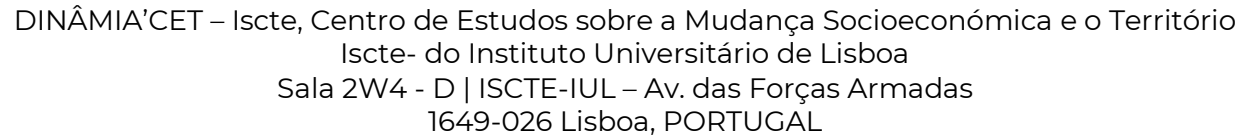


financial assets as a way of leveraging. In Portugal, this households' behaviour was very common in the past, particularly after the $1990 \mathrm{~s}$, due to the privatization of several banks and other public corporations through public offerings in order to promote "popular capitalism' (Barradas et al., 2018). Households incur debt in order to participate in that operations and the respective stocks were used as collateral. As found by Klein (2015), the personal income inequality positively influences Portuguese households' indebtedness, which seems to confirm 'expenditure cascades' behaviour or a 'keeping up with the Joneses' behaviour in Portugal. Finally, the fraction of the working-age population is also a positive influencer of Portuguese households' indebtedness. This result confirms the theoretical predictions that households' indebtedness would be determined by the growing importance of the working-age population, as found by Stockhammer and Wildauer (2018).

Table 7 - The long-term estimates

\begin{tabular}{c|c|c|c}
\hline Variable & Coefficient & Standard Error & T-Statistic \\
\hline House Prices & $-1.089^{* *}$ & 0.389 & -2.797 \\
Financial Asset Prices & $0.248^{* *}$ & 0.086 & 2.884 \\
Personal Income Inequality $_{\mathbf{t}}$ & $26.105^{* *}$ & 9.979 & 2.616 \\
Households' Labour Income $_{\mathbf{t}}$ & $4.048^{* *}$ & 1.609 & 2.516 \\
Welfare State Expenditures $_{\mathbf{t}}$ & 0.283 & 2.151 & 0.131 \\
Working-Age Population $_{\mathbf{t}}$ & $7.774^{* * *}$ & 1.270 & 6.098 \\
Interest Rates & 0.621 & 0.743 & 0.836 \\
@Trend & $0.024^{* * *}$ & 0.007 & 3.238 \\
\hline
\end{tabular}

Note: *** indicates statistical significance at 1\% level, ** indicates statistical significance at $5 \%$ level and $*$ indicates statistical significance at $10 \%$ level

Table 8 contains the short-term estimates for Portuguese households' indebtedness. At the traditional significance levels, the error correction term is statistically significant and exhibits a negative coefficient that lies between -2 and 0 . This confirms the convergence of our model to the long-term equilibrium even when there is a shock in the short-term. The speed of adjustment of any disturbance in the short-term is corrected within a year by approximately $19 \%$. As in the case of the long-term estimates, the degree of personal income inequality and the fraction of the working-age population are also positive

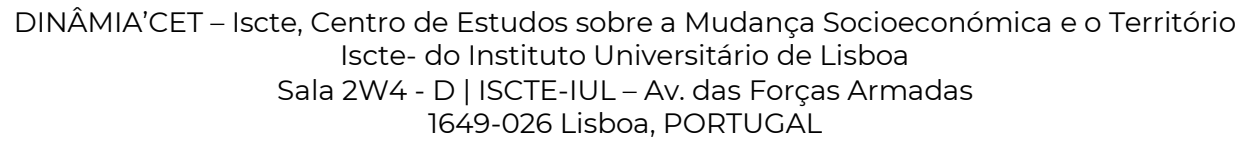


determinants of Portuguese households' indebtedness in the short-term. The high values for the R-squared and the adjusted R-squared indicate that our estimates explain reasonably well the dynamics of Portuguese households' indebtedness. In fact, our estimates explain more than $95 \%$ of the variation in Portuguese households' indebtedness.

Table 8 - The short-term estimates

\begin{tabular}{|c|c|c|c|}
\hline Variable & Coefficient & Standard Error & T-Statistic \\
\hline$\beta_{0}$ & $-0.913 * * *$ & 0.042 & -21.999 \\
\hline$\Delta$ Personal Income Inequality & $2.880 * * *$ & 0.369 & 7.796 \\
\hline$\Delta$ Households' Labour Income $_{t}$ & 0.197 & 0.139 & 1.419 \\
\hline$\Delta$ Working-Age Population ${ }_{t}$ & $0.477 * * *$ & 0.132 & 3.623 \\
\hline$\Delta \mathbf{E C} \mathbf{T}_{\mathrm{t}-1}$ & $-0.190 * * *$ & 0.008 & -22.545 \\
\hline \multicolumn{2}{|c|}{ R-squared $=0.961$} & \multicolumn{2}{|c|}{ Adjusted $R$-squared $=0.954$} \\
\hline
\end{tabular}

Note: *** indicates statistical significance at 1\% level, ** indicates statistical significance at 5\% level and $*$ indicates statistical significance at $10 \%$ level

Table 9 provides the economic effects of the long-term estimates that proved to be statistically significant in order to assess the contribution of each one to the evolution of Portuguese households' indebtedness in the period 1988 to 2016. During that time, Portuguese households' indebtedness had a dissimilar evolution because it exhibited an increasing trend until 2009 and a decreasing trend after that (Figure A1 in the Appendix). Against this backdrop, the analysis of the economic effects is carried out for these two particular periods and for the full period. For these three periods, we use the same longterm coefficients because we have already concluded that our estimates remain stable over time (Figure A2 and Figure A3 in the Appendix). 
Table 9 - The economic effects of long-term estimates

\begin{tabular}{|c|c|c|c|c|}
\hline Period & Variable & $\begin{array}{l}\text { Long-term } \\
\text { Coefficient }\end{array}$ & $\begin{array}{c}\text { Actual Cumulative } \\
\text { Change }\end{array}$ & Economic Effect \\
\hline $\begin{array}{l}\text { Increase of Households' } \\
\text { Indebtedness } \\
(1988-2009)\end{array}$ & $\begin{array}{c}\text { House Prices } \\
\text { Financial Asset Prices } \\
\text { Personal Income Inequality } \\
\text { Households' Labour Income }_{t} \\
\text { Working-Age Population }_{t}\end{array}$ & $\begin{array}{c}-1.089 \\
0.248 \\
26.105 \\
4.048 \\
7.774\end{array}$ & $\begin{array}{c}-0.011 \\
1.195 \\
-0.031 \\
-0.051 \\
-0.011\end{array}$ & $\begin{array}{r}0.012 \\
0.296 \\
-0.809 \\
-0.206 \\
-0.086\end{array}$ \\
\hline $\begin{array}{l}\text { Decrease of Households' } \\
\text { Indebtedness } \\
(2010-2016)\end{array}$ & $\begin{array}{c}\text { House Prices } \\
\text { Financial Asset Prices } \\
\text { Personal Income Inequality } \\
\text { Households' Labour Income } \\
\text { Working-Age Population }_{t}\end{array}$ & $\begin{array}{c}-1.089 \\
0.248 \\
26.105 \\
4.048 \\
7.774\end{array}$ & $\begin{array}{c}-0.066 \\
0.090 \\
-0.002 \\
-0.098 \\
-0.046\end{array}$ & $\begin{array}{l}0.072 \\
0.022 \\
-0.052 \\
-0.397 \\
-0.358\end{array}$ \\
\hline $\begin{array}{l}\text { Full Period } \\
(1988-2016)\end{array}$ & $\begin{array}{c}\text { House Prices } \\
\text { Financial Asset Pricest } \\
\text { Personal Income Inequality } \\
\text { Households' Labour Income }_{t} \\
\text { Working-Age Population }_{t}\end{array}$ & $\begin{array}{c}-1.089 \\
0.248 \\
26.105 \\
4.048 \\
7.774\end{array}$ & $\begin{array}{c}-0.088 \\
1.129 \\
-0.095 \\
-0.068 \\
-0.058\end{array}$ & $\begin{array}{r}0.096 \\
0.280 \\
-2.480 \\
-0.275 \\
-0.451\end{array}$ \\
\hline
\end{tabular}

Note: The actual cumulative change corresponds to the growth rate of the correspondent variable during the respective period. The economic effect is the multiplication of the long-term coefficient by the actual cumulative change

In the period 1988 to 2009 , we conclude that the rise in financial asset prices and the decline in housing prices were the mains drivers of the increase in the Portuguese households' indebtedness. Effectively, the rise in financial asset prices and the decline in housing prices favoured an increase in Portuguese households' indebtedness by about 29.6 and 1.2 per cent, respectively, during that time. Additionally, Portuguese households' indebtedness during that time would have been even higher by about 80.9 per cent if there had not been a fall in personal income inequality, 20.6 per cent if households' labour income had not declined and 8.6 per cent if there had not been a drop in the working-age population.

In the period 2010 to 2016, the decrease in Portuguese households' indebtedness is explained by the reductions in households' labour income, the working-age population and the personal income inequality. They favoured a decrease in Portuguese households' indebtedness by about $39.7,35.8$ and 5.2 per cent, respectively. They also compensated for the prejudicial effects of the decline in housing prices and the rise in financial asset prices. Note that Portuguese households' indebtedness during that time would have even been lower by around 7.2 per cent if there had not been a decline in the housing prices and 2.2 per cent if there had not been a rise in financial asset prices, respectively.

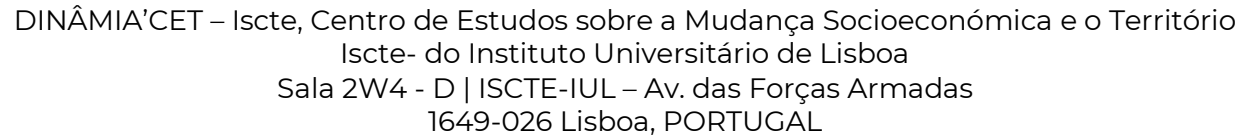


Taking into account the full period, we conclude that the increase in financial asset prices and the decline in housing prices were the main drivers of the Portuguese households' indebtedness, contributing to its increase of about 28.0 and 9.6 per cent, respectively. The reductions in personal income inequality, of the working-age population and households' labour income were not enough to prevent an increase in Portuguese households' indebtedness in the period between 1988 and 2016. In fact, Portuguese households' indebtedness during that time would have been even higher by around 248.0 per cent if there had not been a reduction in personal income inequality, 45.1 per cent if there had not been a decrease in the working-age population, and 27.7 per cent if households' labour income had not declined.

\section{CONCLUSIONS AND POLICY IMPLICATIONS}

The existing literature suggests at least eight macroeconomic determinants of households' indebtedness (Moore and Stockhammer, 2018), namely the rise in housing prices, the upward movements in financial asset prices, the increase in personal income inequality, the decline in households' labour income, welfare state retrenchment, the increase in the working-age population, the low level of interest rates and the greater availability of credit.

From an empirical point of view, there are several empirical and econometric works about households' indebtedness (Kohn and Dynan, 2007; Oikarinen, 2009; Gimeno and Martinez-Carrascal, 2010; Valverde and Fernandez, 2010; Meng et al., 2013; Anundsen and Jansen, 2013; Rubaszek and Serwa, 2014; Klein, 2015; Malinen, 2016; Stockhammer and Wildauer, 2018; Moore and Stockhammer, 2018), but they do not take into account all these eight macroeconomic determinants of households' indebtedness.

This paper developed a time series econometric analysis in order to identify the macroeconomic determinants and the corresponding drivers of Portuguese households' indebtedness in the period 1988 to 2016 . We estimated an equation according to which the Portuguese households' indebtedness depends on the seven macroeconomic 
determinants identified in the existing literature (housing prices, financial asset prices, the degree of personal income inequality, households' labour income, the importance of welfare state expenditures, the fraction of the working-age population and the level of interest rates). As in Moore and Stockhammer (2018), the availability of credit was the only macroeconomic determinant that was not included in our equation due to the absence of a proxy to measure it.

Our estimates were produced through the ARDL estimator due to the existence of variables that are stationary in levels and variables that are stationary in first differences. Our results show that financial asset prices, the degree of personal income inequality, households' labour income and the fraction of the working-age population exert positive influences on Portuguese households' indebtedness, whereas the housing prices exert a negative effect. Our findings also confirm that these macroeconomic determinants drove the evolution of Portuguese households' indebtedness in the last years. In the period 1988 to 2009 , we conclude that the increase in financial asset prices and the decline in housing prices were the main drivers of the increase in Portuguese households' indebtedness during that time. In the period 2010 to 2016, we conclude that the reductions in households' labour income, the working-age population and personal income inequality were the main drivers of the decrease in Portuguese households' indebtedness during that time. Over the full period, the increase in financial asset prices and the decline in housing prices were the main drivers of Portuguese households' indebtedness. Against this backdrop, the Portuguese policy makers should concentrate their efforts on limiting financial asset prices, avoiding the formation of speculative bubbles in the stock markets, and continuing to promote a decrease in personal income inequality in the coming years. Otherwise, households' indebtedness will continue in an upward trend, making the Portuguese economy more vulnerable to any downside risks.

This paper has at least two important shortcomings that should be considered in future research about Portuguese households' indebtedness. Firstly, the macroeconomic determinant related to the availability of credit was not taken into consideration due to the inexistence of a convenient proxy to assess it. However, the higher availability of 
credit is particularly relevant in Portugal for explaining the evolution of households' indebtedness due to the arrival of foreign banks and the easier access of banks to European financial markets via euro interbank, or even to the liquidity mechanisms provided by the European Central Bank (Barradas et al., 2018). Secondly, this paper followed a macroeconomic perspective in order to identify the macroeconomic determinants and the respective drivers of Portuguese households' indebtedness as a whole. As such, we cannot be certain our results are common among the majority of households, or they would be quite different depending on the characteristics of households, such as wealth, income, qualifications, occupation, size, age, among others. The use of micro data at the household-level could be promising in this respect.

\section{REFERENCES}

Anundsen, A. K., and Jansen, E. S. (2013). Self-Reinforcing Effects between Housing Prices and Credit. Journal of Housing Economics, 22, 3, 192-212.

Barba, A., and Pivetti, M. (2008). Rising Household Debt: Its Causes and Macroeconomic Implications - a Long-Period Analysis. Cambridge Journal of Economics. 33 (1): 113-137.

Barradas, R. (2016). Evolution of the Financial Sector - Three Different Stages: Repression, Development and Financialisation. In O. Gomes, and H. F. Martins (ed.) Advances in Applied Business Research: the L.A.B.S. Initiative. New York: Nova Science Publishers.

Barradas, R. (2019.) Financialization and Neoliberalism and the Fall in the Labor Share: A Panel Data Econometric Analysis for the European Union Countries. Review of Radical Political Economics. 51, 3, 383-417.

Barradas, R. (2020). Drivers of Private Consumption in the Era of Financialization: New Evidence for the European Union Countries. Review of Radical Political Economics. Forthcoming. 
Barradas, R., and Lagoa, S. (2017). Functional Income Distribution in Portugal: The Role of Financialisation and Other Related Determinants. Society and Economy, 39, 2, 183-212.

Barradas, R., Lagoa, S., Leão, E., and Mamede, R. P. (2018). Financialisation in the European Periphery and the Sovereign Debt Crisis: The Portuguese Case. Journal of Economic Issues, 52, 4, 1056-1083.

Bernanke, B., Gertler, M., and Gilchrist, S. (1996). The Financial Accelerator and the Flight to Quality. The Review of Economics and Statistics, 78, 1, 1-15.

Boone, L., and Girouard, N. (2002). The Stock Market, The Housing Market and Consumer Behaviour. OECD Economic Studies, 35. Paris.

Brooks, C. (2009). Introductory Econometrics for Finance. $2^{\text {nd }}$ Edition. New York: Cambridge University Press.

Cooper, D., and Dynan, K. (2016). Wealth Effects and Macroeconomic Dynamics. Journal of Economic Surveys. 30, 1, 34-55.

Dickey, D. A., and Fuller, W. A. (1979). Distribution of the Estimators for Autoregressive Time Series with a Unit Root. Journal of the America Statistical Association, 74, 366, 427-431.

Duesenberry, J. S. (1949). Income, Saving and the Theory of Consumer Behaviour. Cambridge: Harvard University Press.

Edison, H., and Sløk, T. (2001). Wealth Effects and the New Economy. IMF Working Paper, 77, Washington.

Finlayson, A. (2009). Financialisation, financial literacy and asset-based welfare. The British Journal of Politics and International Relations, 11, 400-421.

Frank, R. H., Levine, A. S., and Dijk, O. (2014). Expenditure Cascades. Review of Behavioral Economics, 1, 1-2, 55-73.

Gimeno, R., and Martinez-Carrascal, C. (2010). The Relationship between House Prices and House Purchase Loans: The Spanish Case. Journal of Banking and Finance, 34, 8, 1849-1855.

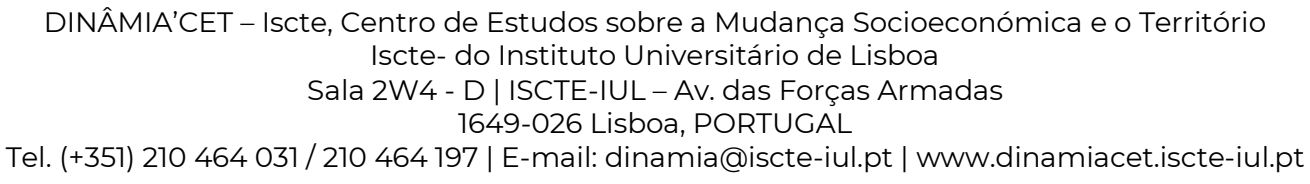


Godley, W., and Lavoie, M. (2007). Monetary Economics. New York: Palgrave Macmillan.

Hein, E. (2012) The Macroeconomics of Finance-dominated Capitalism - and its Crisis. Cheltenham: Edward Elgar Publishing Limited.

Homburg, S. (2000). Compulsory savings in the welfare state. Journal of Public Economics. 77, 2, 233-239.

Justiniano, A., Primiceri, G. E., and Tambalotti, A. (2019). Credit supply and the Housing Boom. Journal of Political Economy, 127, 3, 1317-1350.

Klein, M. (2015). Inequality and Household Debt: A Panel Cointegration Analysis. Empirica, 42, $2,391-412$.

Kohn, D., and Dynan, K. (2007). The Rise in U.S. Household Indebtedness: Causes and Consequences. The Structure and Resilience of the Financial System. Proceeding of a Conference. Sydney: Reserve Bank of Australia.

Kutner, M., Nachtsheim, C., Neter, J., and Li, W. (2004). Applied Linear Statistical Models. $5^{\text {th }}$ Edition. New York: Irwin/McGraw-Hill.

Lagoa, S., and Barradas, R. (2020). Financialisation and Inequality in the Semi-Periphery: Evidence from Portugal. In A. C. Santos, and N. Teles (eds.), Financialisation in the European Periphery: Work and Social Reproduction in Portugal. London: Routledge.

Lapavitsas, C. (2011). Theorizing financialization. Work, Employment and Society. 25, 4, 611626.

Lapavitsas, C. (2013). Profiting without Producing. How Finance Exploits Us All. London: Verso.

Ludwig, A., and Sløk, T. (2002). The Impact of Changes in Stock Prices and House Prices on Consumption in OECD Countries. IMF Working Paper, 1, Washington.

Lütkepohl, H. (1991). Introduction to Multiple Time Series Analysis. New York: Springer-Verlag.

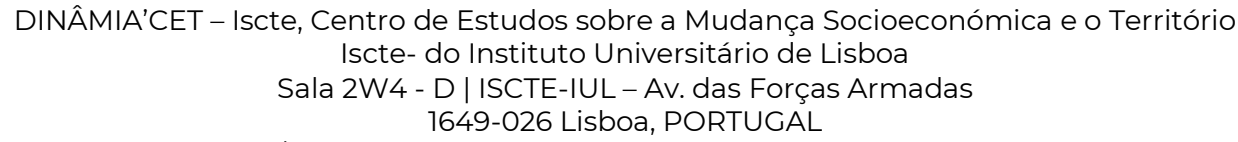


Malinen, T. (2016). Does Income Inequality Contribute to Credit Cycles? The Journal of Economic Inequality, 14, 3, 309-325.

McCloskey, D. N., and Ziliak, S. T. (1996). The Standard Error of Regressions. Journal of Economic Literature, 34, 1, 97-114.

Meng, X., Hoang, N. T., and Siriwardana, M. (2013). The Determinants of Australian Household Debt: A Macro Level Study. Journal of Asian Economics, 29, 80-90.

Mian, A., and Sufi, A. (2014). House of Debt: How They (and You) Caused the Great Recession, and How We Can Prevent It from Happening Again. Chicago: University of Chicago Press.

Modigliani, F., and Brumbergh, R. (1954). Utility Analysis and the Consumption Function: An Interpretation of Cross-section Data. In K. Kurihara (ed.) Post Keynesian Economics. New Brunswick: Rutgers University Press.

Moore, G. L., and Stockhammer, E. (2018). The drivers of household indebtedness reconsidered: An empirical evaluation of competing arguments on the macroeconomic determinants of household indebtedness in OECD countries. Journal of Post Keynesian Economics, 41, 4, 547 577.

Narayan, P. K. (2005). The saving and investment nexus for china: evidence from cointegration tests. Applied Economics, 37, 17, 1979-1990.

Oikarinen, E. (2009). Interaction between Housing Prices and Household Borrowing: The Finnish Case. Journal of Banking and Finance, 33, 4, 747-756.

Pesaran, M. H. (1997). The Role of Economic Theory in Modelling the Long Run. Economic Journal, 107, 1, 178-191.

Pesaran, M. H., and Shin, Y. (1999). An Autoregressive Distributed-Lag Modelling Approach to Cointegration Analysis. In S. Strøm (ed.) Econometrics and Economic Theory in The Twentieth Century: The Ragnar Frisch Centennial Symposium. Cambridge: Cambridge University Press. 
Pesaran, M. H., Shin, Y., and Smith, R. J. (2001). Bounds Testing Approaches to The Analysis of Level Relationships. Journal of Applied Econometrics, 16, 1, 289-326.

Phillips, P. C. B., and Perron, P. (1998). Testing for a Unit Root in Time Series Regression. Biometrika, 75, 2, 335-346.

Rubaszek, M., and Serwa, D. (2014). Determinants of Credit to Households: An Approach Using the Life-Cycle Model. Economic Systems, 38, 4, 572-587.

Ryoo, S. (2016). Household Debt and Housing Bubbles: A Minskian Approach to Boom-Bust Cycles. Journal of Evolutionary Economics, 26, 5, 971-1006.

Stockhammer, E. (2009). The finance-dominated accumulation regime, income distribution and the present crisis. Papeles de Europa, 19, 58-81.

Stockhammer, E. (2010). Financialization and the Global Economy. Political Economy Research Institute Working Paper 240.

Stockhammer, E. (2012). Financialisation, Income Distribution and The Crisis. Investigación Económica, 71, 279, 39-70.

Stockhammer, E. (2015). Rising Inequality as a Cause of the Present Crisis. Cambridge Journal of Economics, 39, 3, 935-958.

Stockhammer, E., and Wildauer, R. (2018). Expenditure Cascades, Low Interest Rates or Property Booms? Determinants of Household Debt in OECD Countries. Review of Behavioral Economics, $5,2,85-121$.

Studenmund, A. H. (2005). Using Econometrics: A Practical Guide. $5^{\text {th }}$ Edition, Boston: Addison Wesley Pearson.

Taylor, J. B. (2009). The Financial Crisis and the Policy Responses: An Empirical Analysis of What Went Wrong. NBER Working Paper, 14631.

Tridico, P., and Pariboni, R. (2018). Inequality, financialization, and economic decline. Journal of Post Keynesian Economics, 41, 2, 236-259.

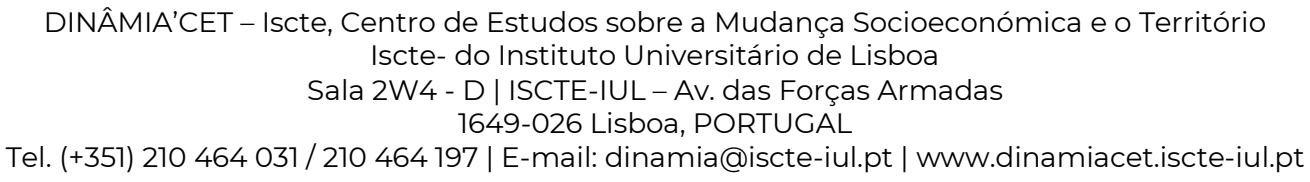


Van Der Zwan, N. (2014). Making sense of financialization. Socio-Economic Review, 12, 1, 99129.

Valverde, C., and Fernandez, F. (2010). The Relationship between Mortgage Markets and House Prices: Does Financial Instability Make the Difference?. CenFIS Working Paper 10-02.

Wooldridge, J. M. (2003). Introductory Econometrics: A Modern Approach. $2^{\text {nd }}$ Edition. Ohio: Thomson South-Western.

Ziliak, S. T., and McCloskey, D. N. (2004). Size matters: the standard error of regressions in the American Economic Review. The Journal of Socio-Economics, 33, 5, 527-54. 


\section{APPENDIX}

Figure A1 - Plots of the variables
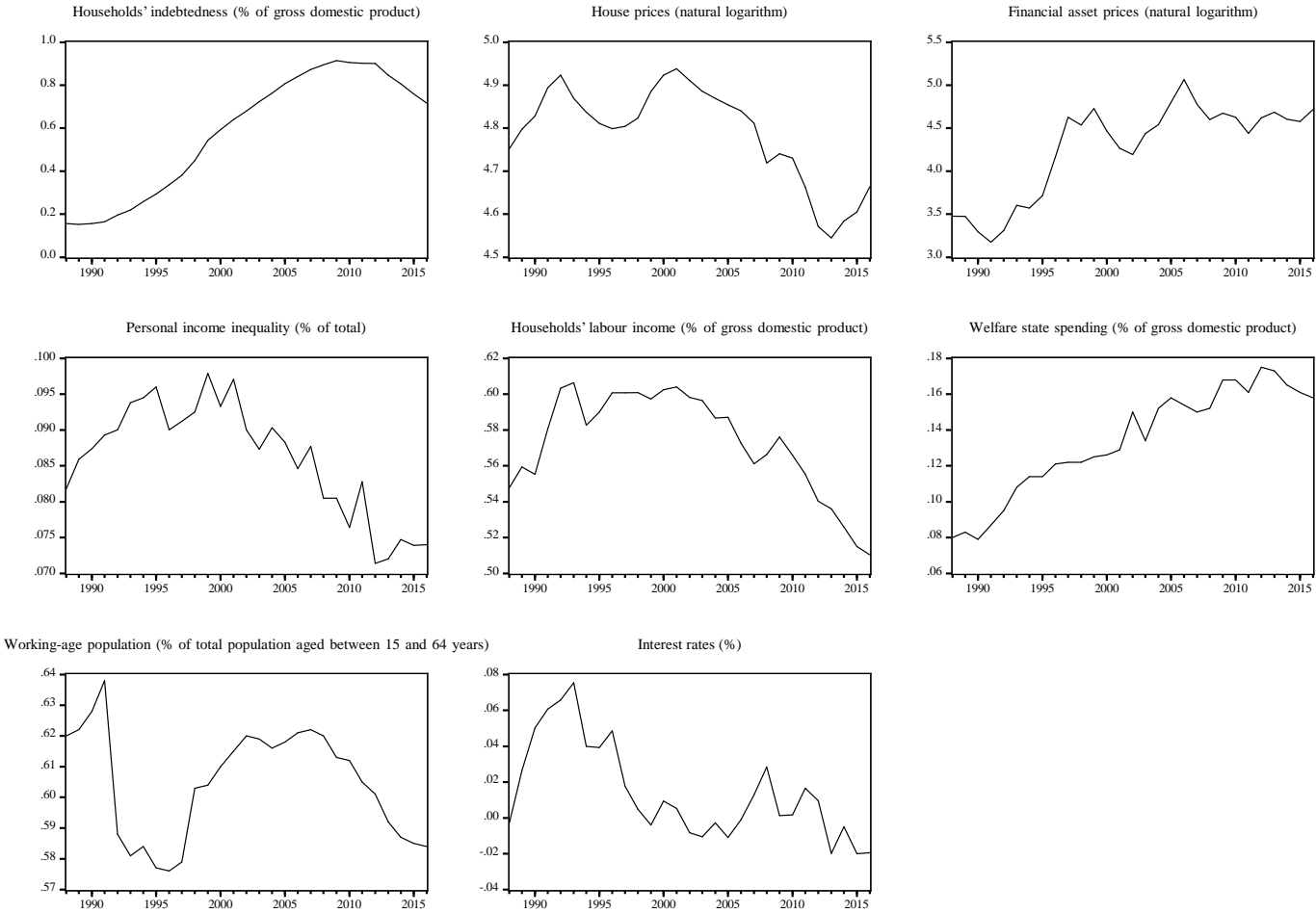

Figure A2 - The CUSUM test

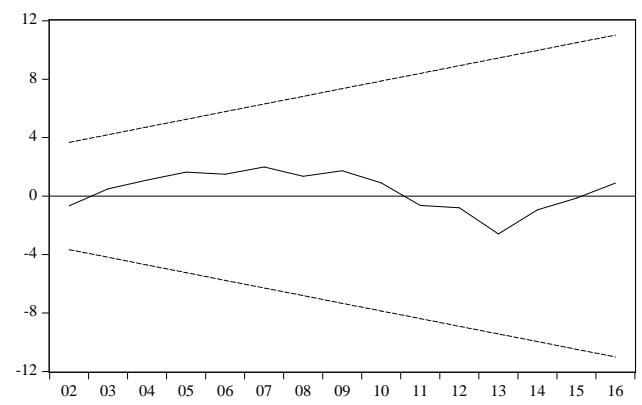

DINÂMIA'CET - Iscte, Centro de Estudos sobre a Mudança Socioeconómica e o Território Iscte- do Instituto Universitário de Lisboa

Sala 2W4 - D | ISCTE-IUL - Av. das Forças Armadas

1649-026 Lisboa, PORTUGAL

Tel. (+351) 210464031 / 210464197 | E-mail: dinamia@iscte-iul.pt | www.dinamiacet.iscte-iul.pt 
Figure A3 - The CUSUMSQ test

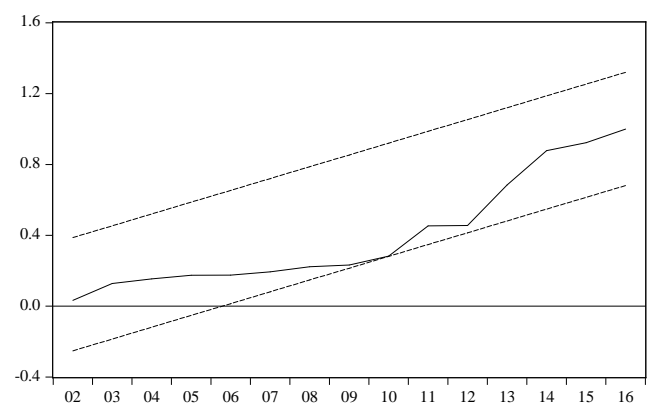

DINÂMIA'CET - Iscte, Centro de Estudos sobre a Mudança Socioeconómica e o Território Iscte- do Instituto Universitário de Lisboa

Sala 2W4 - D | ISCTE-IUL - Av. das Forças Armadas

1649-026 Lisboa, PORTUGAL

Tel. (+351) 210464031 / 210464197 | E-mail: dinamia@iscte-iul.pt | www.dinamiacet.iscte-iul.pt 